\title{
Factors Attracting Consumers to Visit Community Pharmacies in Malaysia
}

\author{
Steffi Ong Wei Mei*, Yim Jing Yee** \\ * Bachelor of Pharmacy, Faculty of Pharmacy International Medical University, Malaysia \\ ** Bachelor of Pharmacy, Faculty of Pharmacy International Medical University, Malaysia \\ DOI: 10.29322/IJSRP.11.09.2021.p11763 \\ http://dx.doi.org/10.29322/IJSRP.11.09.2021.p11763
}

\begin{abstract}
This research aims to identify factors that attract consumers to visit Community Pharmacies in Malaysia. Good customer service, engagement and professionalism provided by staff, sales promotion, environment, and convenience of the pharmacy are the factors to attract and retain more customers. Alpro Pharmacy is selected for this research study due to its fast expansion of business/outlets. Also, it is being recognized as the number one prescription pharmacy in Malaysia. A mystery shopper survey was implied in selected Alpro pharmacy outlets from January to July 2021. A total of 200 mystery shoppers were sent out to all the outlets and the results obtained were purely based on the rating and percentage from the Likert scale (4 - Agree and 5 - Strongly Agree). The existing health screen has been found to be the main attracting factor, followed by customer services, an extensive array of products selection, and rapport-building skills. Intriguingly, staff professionalism and location of the pharmacy had the least impacts on customers' satisfaction.
\end{abstract}

Index Terms- Community Pharmacy, Alpro Pharmacy, No.1 Prescription Pharmacy in Malaysia, Customer Services, Staff Professionalism.

\section{INTRODUCTION}

Community Pharmacies in Malaysia are said to be one of the easiest accesses to healthcare professionals for the public. It offers patients or customers personalised medical advice on a walk-in basis. As of $31^{\text {st }}$ December 2018, the Malaysian Pharmacists Society (MPS) reported that there were a total of 2889 Community Pharmacies in Malaysia, and the numbers are still growing rapidly [1]. Due to the Covid-19 pandemic and Movement Control Order (MCO) implemented by the federal government of Malaysia, the walk-in rate, and the purchasing power of the public on medical products have been increasing. There is an increase in demand for facemasks, face shields, sanitisers, supplements, and Over the Counter (OTC) products as well as medications. For community pharmacies to grow and expand their business, attracting and gaining new customers are the main keys to success. Besides that, retaining customers is equally important too. According to Smith (2005), customer retention creates more value for business due to low operating costs and is less time consuming compared to gaining new customers [2]. Existing customers may create more word-of-mouth referrals as they have experienced the services provided by the respective community pharmacy [3].

\section{LITERATURE REVIEW}

According to Schiffman (2007), consumer behavior is the behavior that customers display in searching, purchasing, using, evaluating, and disposing of a product or service for personal needs [4]. Thus, for businesses in the community pharmacies to grow and expand, proper communication and building strong customer relationships are essential to identify and fulfil customers' needs. Good customer services, professionalisms, sales promotion, environment, and location of the pharmacy are the few main strategies to get a steady stream of the customer.

\section{A. Customer Services and Engagement}

Customer service is an essential retailer activity that can increase the value received by the consumers [5]. In Community Pharmacy, pharmacists are the customer service representatives who have direct contact with the customers. The customers' perceptions of the whole pharmacy and the product are shaped in part by their experience and satisfaction communication with the staff [6]. According to Wreden (2004), professional customer service should include attention, smile, enthusiasm, courteous words, warmth, patience, understanding, sincerity, consideration, and appreciation [7]. Customer service in Community Pharmacy must be tailored to meet customers' expectations and ensure their satisfaction [8]. Many studies regarding service business, customer relationship management, and retail marketing have been focusing on customer engagement. Customer engagement is the intensity of an individual's participation 
in and connection with an organization's offerings or organizational activities, which either the customer or the organization initiates [9]. Although it takes effort and time to develop a customer service plan, but it may build a positive word of mouth and indirectly retaining the customers.

\section{B. Staff Professionalism}

Professionalism reflects a staff's image, attitude and communication towards a customer and their colleague in a work environment Being professional is essential as it ensures a positive first impression. In the healthcare industry, especially in pharmacies, professionalism is gaining increasing attention [10]. Pharmacies are one of the primary healthcare services providers by providing advice or counselling about health and medications to the patients, thus the pharmacy staff including the pharmacists, nutritionists, dietitians, and health advisors must be professional [11]. Professionalism is not only based on the staff's behavior, but also reflects the professional competence of a physician [12]. The professionalism displays on the staff will indirectly improve the relationships with customers, increase customer retention as well as increase the sales for the pharmacy [13].

\section{Sales Promotion}

In marketing, sales promotion is defined as a collection of incentive tools designed to stimulate the quicker or greater purchase of a particular product or service by customers in a limited time [14]. According to Aashish (2021), sales promotion is a part of the marketing mix where short-term customer-oriented strategies are employed to stimulate the demand for the products by increasing their attractiveness [15]. It is also a marketing technique that is used to entice customers to purchase a product that typically lasts for a set period and is used to achieve a specific purpose, such as increasing market share or unveiling a new product [16]. Sales promotions are effective at achieving a quick boost in sales of the pharmacy and introduce customers to new products [17]. The medicine price is also one of the factors affecting repeated purchases and customer loyalty in different countries [18]. Customers may compare the prices among different companies to find the best deals. Former Health Minister, Datuk Seri Dr. Dzulkefly bin Ahmad, has proposed the controlling on medicine prices, even though general practitioners, pharmacists, private hospitals, and both local and multinational pharmaceutical companies have opposed legislated drug price ceilings [19]. Hence, a more comprehensive discussion is needed to come to a unanimous agreement.

\section{Environment and Convenience}

The environment and the convenience of a Community Pharmacy are some of the attractive factors for people to visit a community pharmacy. The physical environment of a store is referring to the tangible, or material, objects, and conditions that surround a business [20]. It is one of the most important factors that affect customers' store selection, as it has a positive effect on customers' purchasing attitudes and their commitment [21]. Convenience is mentioned as the factor attracting consumers to shop in the physical shop. Convenience is seen from the shoppers' perspective as their preferred shopping outlets are based on the operation hour and the travelling time [22]. In other words, convenience not only saves time, but also reduces the stress, cost, and other expenditures of a consumer which is an instrumental attribute in pharmacy retail success since convenience dimensions have significant importance in retailing and play an important role in customer store choice [23].

\section{METHODS}

The study was conducted in Community Pharmacy outlets across Malaysia. Alpro Pharmacy was selected for this research study due to its fast-expanding and growing business. Alpro Pharmacy is now rooted at more than 135 locations across Malaysia and is being recognized as the number one prescription pharmacy chain in Malaysia [24]. The research was carried out from $1^{\text {st }} \mathrm{Jan}$ to $31^{\text {st }} \mathrm{July} 2021$ in which a total of 200 mysterious shoppers was recruited online for this research. Each mystery shopper will receive a reward of RM50 cash in return once they have submitted their mystery shopper report. According to Finn (2001), a mystery shopper is seen as one of the most efficient instruments to gain in-depth knowledge of the customer's perception and the feeling of the services delivered by a seller [25].

Observation on the pharmacists and staff's behavior, the time spent for waiting, outlet interior \& atmosphere, appearance and the tidiness of the pharmacy and other features which can influence the success of the selling transaction was conducted during the mystery shopper visit [26]. The population of this research consists of mystery shoppers who made the purchase decision from the pharmacies for themselves or on behalf of their family members. According to the National Health and Morbidity Survey 2019, a family in Malaysia is reported to spend approximately 5.1\% from their total household monthly expenditure on healthcare products [27]. This is said to be increase by the following year as the spike of the Covid-19 cases in Malaysia. Public spend more in purchasing facemask, sanitizer or even a self-test Covid-19 test kit.

Six main survey questions were asked in the mystery shopper form by using a 5-Point Likert Scale. A 5-Point Likert Scale is a type of psychometric response scale in which responders specify their level of agreement to a statement typically in five points: (1) 
Strongly disagree; (2) Disagree; (3) Neither agree nor disagree; (4) Agree; (5) Strongly agree [28]. Each response was assigned with a point value, and an individual's score was determined by adding up the point values of all the statements [29]. The mysterious shoppers were required to record their observations in a form of paper prepared specifically for this research purpose. A Likert rating scale measurement can be a useful and reliable instrument for measuring self-efficacy [30].

A total of 200 copies of the mystery survey form were returned and the response rate was 100 percent. Table 1 showed the details of the 200-mystery shoppers which included their age, gender, marital status, monthly income, the state of Alpro Pharmacy was visited, and the types of products bought.

\begin{tabular}{|c|c|c|c|c|c|c|c|}
\hline Variable & Category & Counts & Percentage (\%) & Variable & Category & Counts & $\begin{array}{c}\text { Percentage } \\
(\%)\end{array}$ \\
\hline \multirow{4}{*}{ Age } & $\leq 30$ & 53 & 26.50 & \multirow{3}{*}{ Monthly Income } & $\leq \mathrm{RM} 1500$ & 56 & 28.00 \\
\hline & $31-40$ & 72 & 36.00 & & RM1501 - RM2500 & 88 & 44.00 \\
\hline & $41-50$ & 75 & 37.50 & & $\geq \mathrm{RM} 2501$ & 56 & 28.00 \\
\hline & Total & 200 & 100.00 & & Total & 200 & 100.00 \\
\hline \multirow{3}{*}{ Gender } & Males & 91 & 45.50 & \multirow{12}{*}{$\begin{array}{l}\text { State of Alpro } \\
\text { Pharmacy visited }\end{array}$} & PNegeri Sembilan & 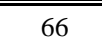 & 33.00 \\
\hline & Females & 109 & 54.50 & & Kuala Lumpur & 18 & 9.00 \\
\hline & Total & 200 & 100.00 & & Selangor & 15 & 7.50 \\
\hline \multirow{4}{*}{ Marital Status } & Single & 55 & 27.50 & & Pahang & 16 & 8.00 \\
\hline & Married & 104 & 52.00 & & Terengganu & 14 & 7.00 \\
\hline & Others & 41 & 20.50 & & Johor & 10 & 5.00 \\
\hline & Total & 200 & 100.00 & & Melaka & 19 & 9.50 \\
\hline \multirow{6}{*}{$\begin{array}{c}\text { Types of } \\
\text { products bought }\end{array}$} & OTC & 44 & 22.00 & & Penang & 15 & 7.50 \\
\hline & $\begin{array}{l}\text { Homecare } \\
\text { products }\end{array}$ & 32 & 16.00 & & Kelantan & 10 & 5.00 \\
\hline & Supplement & 56 & 28.00 & & Kedah & 2 & 1.00 \\
\hline & Personal care & 19 & 9.50 & & Perak & 3 & 1.50 \\
\hline & $\begin{array}{l}\text { Prescribed } \\
\text { medicine }\end{array}$ & 49 & 24.50 & & Sarawak (EM) & 12 & 6.00 \\
\hline & Total & 200 & 100.00 & & Total & 200 & 100.00 \\
\hline
\end{tabular}

\section{ANALYSE FINDINGS}

Six main survey questions were asked in the mystery shopper research form by using a 5-Point Likert Scale rating. All results are shown below (Figure 1 to 6). Most of the mystery shoppers were female with income from RM1501 to RM2500 and age around $41-50$ years old. The study was carried out in 12 different states in Malaysia. There is only one outlet located in Perak and Kelantan respectively, therefore the results received from the two states was the lowest among others. Lastly, different type of products was purchased during the visit varies between 5 categories. During this Covid-19 pandemic, we could see that most of the products bought were health supplements and prescribed medicine, followed by OTC products, Homecare products which included wheelchair, and lastly personal care products.

\section{A. Customer Service and Information Given by Alpro Pharmacy is Better Compared to Others,}

Customer service is the support and professional advice offered by the company to the customers in making choices for cost-effective and useful products [31]. Good customer service by meeting customer's expectations is essential to help the pharmacy to stay competitive. Alpro Pharmacy has designated its priority to provide excellent customer service and attend to all customers' needs. According to research carried out in Malaysia, the most common requests made by customers in the community pharmacy were medications via their brand names [32]. However, there were only a few prescriptions received by the pharmacies. Also, research carried out by Okai et.al shows that more than $50 \%$ of the residents will seek for treatments in community pharmacies for minor ailments [33]. However, some of the medications need a doctor's prescription for dispensing. To be more comprehensive, Alpro Pharmacy has a collaboration with Doc2Us to provide a one-to-one teleconsultation with the professional doctors before dispensing the medications fall under group B. The main key features of good customer service in the pharmacy are not just about the knowledge and skills of the staff but also include patience, respect, engage and communication skills [34]. From the survey, we can clearly see that the team has been equipped with up-to-date knowledge and proper training to satisfy all customer's enquiries as $81.5 \%$ (Figure 1) of the mystery shoppers agreed that the level of customer service and information given by Alpro Pharmacy is better. 


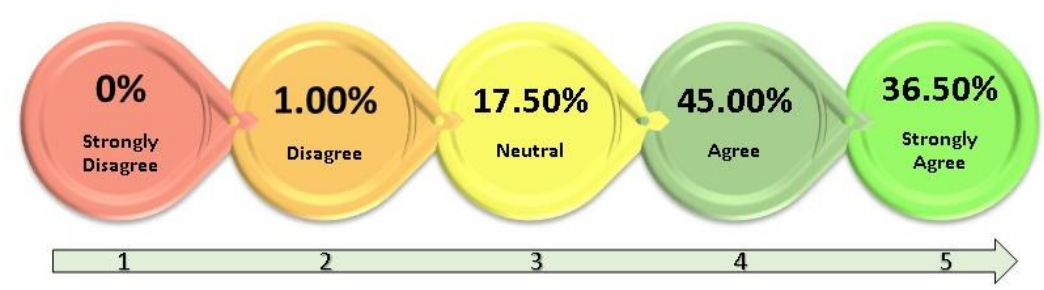

Figure 1: Customer service and information given by Alpro Pharmacy is better compared to others.

\section{B. Alpro Pharmacy Staff Is Professional and Rapport Building Skills of Staff is Trustworthy.}

Professionalism is the skills and qualities that are expected to show in a person in his working field which is fundamental in operating a business. In Community Pharmacy, professionalism includes behaviors, attitudes, attires, and professional knowledge [34]. A professional staff should acquire the skills of addressing the customers' concerns and needs, giving suggestions, and assisting them to decide on the most suitable plan [35]. Although strong sales and management skills are crucial in pharmacy operation, providing professional services and building rapport with the customers may result in positive reviews and more customer retention. All the staffs in Alpro Pharmacy, including sales assistants, pharmacist assistants, nutritionists, and pharmacists are believed to equip with the skills via staff training or product training. In this study, we assessed the quality of service, counselling, and professional knowledge given by the staff. More than half of the mystery shoppers claimed that they were greeted by the staff with welcoming smiles. While serving the customers, the staffs also respond in a calm and courteous matter. They feel comfortable during the conversation. This interaction indirectly builds the rapport between the staff and the customers, and thus, creates a feeling of trust in the Alpro Pharmacy. As a result, 76\% (Figure 2) of the mystery shoppers agreed that the Alpro Pharmacy staffs were professional during purchase and after-sales consultation. Additionally, 76.50\% (Figure 3) of them recognize the rapport-building skills of the Alpro Pharmacy staff. They claimed that the Alpro Pharmacy is a trustworthy Community Pharmacy that they will seek for professional help.

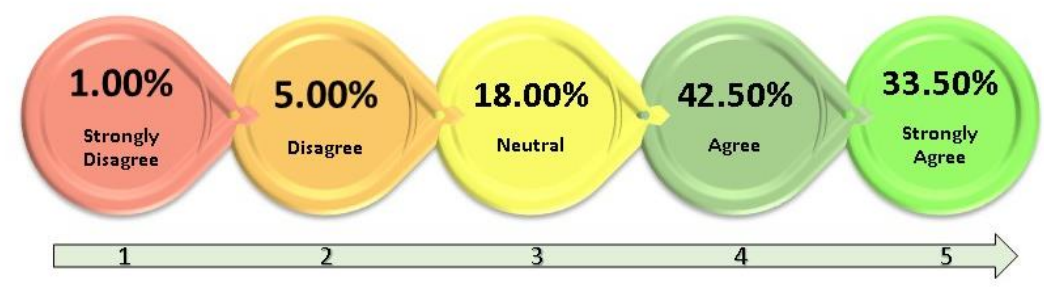

Figure 2: Alpro Pharmacy staff is professional during purchase \& after sales consultation.

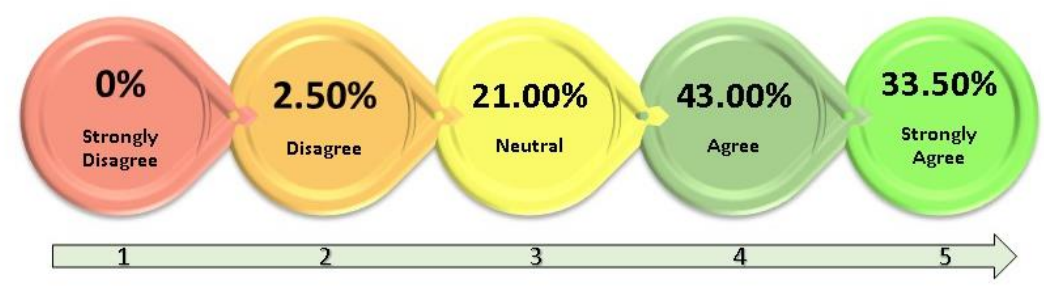

Figure 3: Rapport building skills of Alpro Pharmacy's staff and being trustwor thy.

\section{Availability of Health Screenings in Alpro Pharmacy}

Health screening is one of the crucial measures to discover an illness or health condition earlier, even if no symptoms or any indicators of the disease have appeared. Also, health screening should be the top priority for everyone to promote good health [36]. Hence, there are some benefits of health screening, for instance, people with a family history of cardiovascular disease, stroke, or diabetes can benefit from health screening due to its ability to help those family members prevent disease and receive appropriate treatment at the meant time. Besides that, aging is an important risk factor for a wide range of life-altering diseases. Early detection and the right treatment may provide the body with the best defense against these diseases which improve the quality of life. Therefore, with the vision encouraged by Alpro Pharmacy "for a healthy and vibrant world", Alpro Pharmacy provides free high blood pressure tests in all the outlets [37]. To provide the best service to the community, all employees in Alpro Pharmacy receive instruction and medical training on how to operate the medical equipment, interpret the results, and follow the protocols in performing health screening and medication management tests. Thus, it gives confidence to the community and became one of the preferred pharmacies chosen by consumers compared to other pharmacies. Despite the pandemic period, Alpro pharmacy still provides health screening services to the community. This showed that the pharmacy holds to its responsibilities towards everyone during this difficult time. This statement was eventually agreed upon by $84 \%$ (Figure 4) of mystery shoppers. 


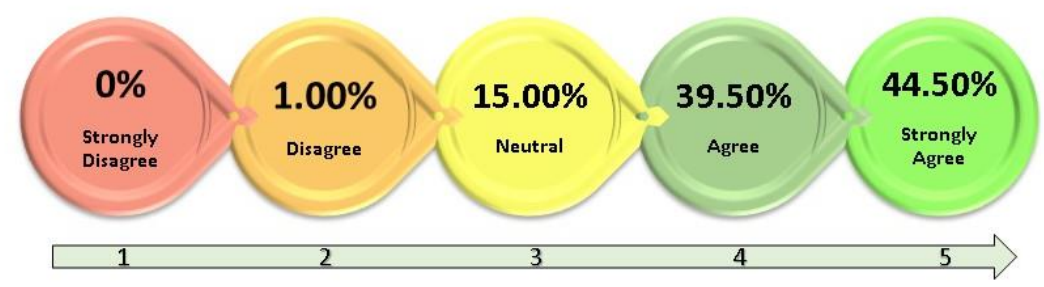

Figure 4: Availability of Health Screenings in Alpro Pharmacy.

\section{Extensive Array of Products and Having the Latest Products to Recommend and Share with Customer}

The success of product marketing in any company or aspect, large or small, very much depending on the availability of a diverse range of items [38]. Therefore, it is important to have a wide range of products in pharmacy. This is because having a diverse product line enhances the likelihood of satisfying more clients while also increasing productivity [39]. Besides that, the products that are shared and introduced are carefully chosen so that retail employees can provide a broad variety of knowledge about what is available in the pharmacy and provide it to clients. On the other hand, those promotions and updated news are available not just in the pharmacy but also available online. Hence, consumers can get the promotion with just a visit to the Alpro Pharmacy website, and a variety of products also available with just one click away [40]. Moreover, retail skills training is also provided to Alpro Pharmacy employees. Selling of products or services come up with giving accurate information to the customers are essential because, with the skillful service, the staff is better able to service customers eventually built confident towards customers and make Alpro Pharmacy becomes the first choice of pharmacy service when necessary. Meanwhile, to ensure all the staffs are up to date to the latest promotion available for instance Member's Days or Warehouse sales and latest products knowledge, morning briefing is given before business hours. This statement is agreed with $79 \%$ (Figure 5) of the mystery shopper.

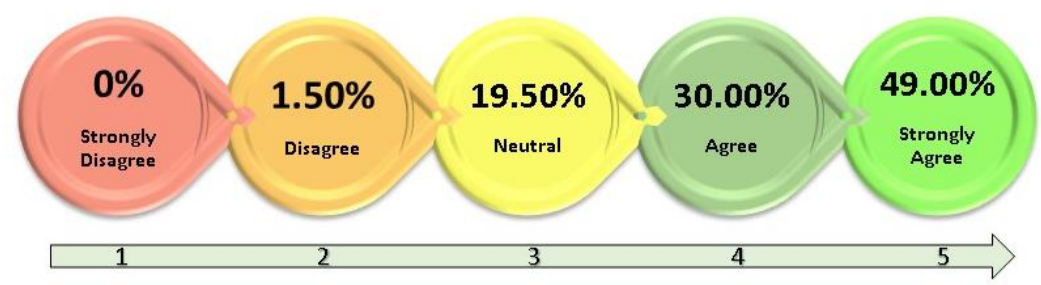

Figure 5: Extensive array of products and having the latest products to recommend and share with customer.

\section{E. Location and Environment in Alpro Pharmacy}

It is critical to consider the location and internal environment of Alpro pharmacy outlets to ensure the commercial success of business in the long run. Under the leadership and vision of the Alpro Management team alongside strong support from retail staff, Alpro Pharmacy has successfully grown to a popular pharmacy chain household name with more than 135 outlets throughout Malaysia [24]. Furthermore, in the year 2020, Alpro Pharmacy has aggressively opened more than 20 new outlets, thus achieving solid revenue growth of more than $300 \%$ in comparison to the year 2019 [24]. Alpro Pharmacy needs to identify the key factors such as population density within the neighborhood, convenience, and accessibility for customers, nearby external businesses that draws community within the area to complement Alpro pharmacy business [41]. The internal factors that provide a pleasant and comfortable shopping experience for customers also play an important role. Environmental factors engaging shoppers' senses of sight, hear, smell, taste, and touch can help to motivate shoppers in their decision making to purchase [41]. For instance, Alpro Pharmacy engages the use of free products sampling, visual and promotional aids, indoor music, air fresheners at every outlet to maximize the overall shopping experience. This statement was agreed upon by $76 \%$ (Figure 6) of the mystery shoppers.

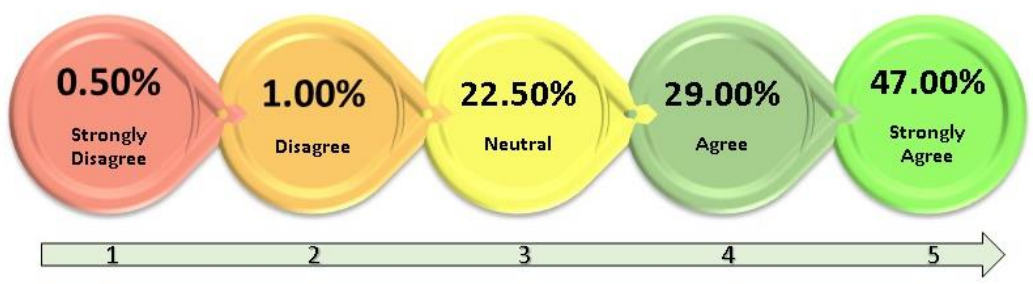

Figure 6: Location and Environment at Alpro Pharmacy. 


\section{CONCLUSION}

Good customer services, engagement and professionalism provided by staff, sales promotion, environment, and convenience of the pharmacy are said to be the factors that attract customers to visit Community Pharmacy in Malaysia. Figure 7 above showed a conclusion of the research that the availability of health screening in Alpro Pharmacy was the main factor that attract customers to visit the pharmacy. This is followed by customer services, an extensive array of selection of products, and rapport-building skills. Staff professionalism and location of the pharmacy have the least impact on customers' decisions. Through customer satisfaction and loyal feedbacks from the study, the managing level of a business can ensure a way of knowing what the customer thinks about their service and what needs to be Kaizen to gain positive customer satisfaction. Kaizen, a Japanese term that defines "change for the better" or "continuous improvement" is a business philosophy regarding the processes that continuously improve operations that involve all employees by making the working environment more efficient [42]. With all these positive attitudes and behavior, building a healthy and vibrant world is just one step away.

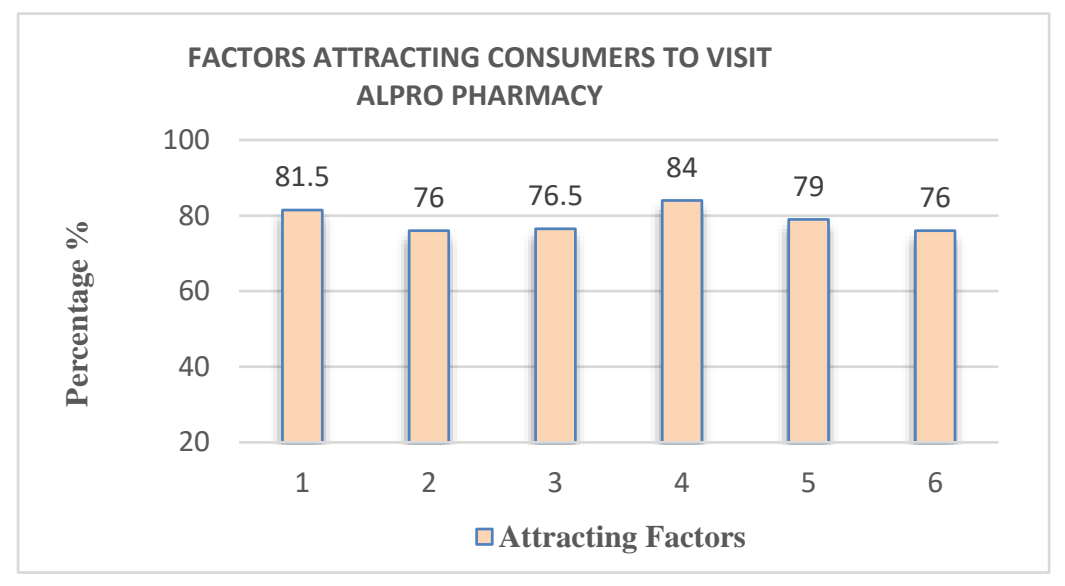

Legend: Attracting Factors

1 The level of customer service and information given by Alpro Pharmacy is better.

2 Alpro Pharmacy staff's professionalism during purchase \& after sales consultation.

3 Rapport building skills of Alpro Pharmacy's staff and being trustworthy enough to have my best interest at hand.

4 Availability of Health Screenings in Alpro Pharmacy.

5 Extension array of selections of products and having the latest products to recommend and share with customer.

6 Location and Environment at Alpro Pharmacy.

Figure 7: Factors attract consumers to visit Alpro Pharmacy.

\section{REFERENCES}

[1] Tan Zhi Shan, Sujata (RPh 14569). (2019), Analysis Report: Distribution of Poison License A Holders and Community Pharmacies in Malaysia. Available at: file:///D:/Documents/Downloads/Distribution\%20of\%20Type\%20A\%20Licence\%20Holders\%20and\%20Community\%20Pharmacies\%20in\%20Malaysia.pdf (Accessed July 15, 2021).

[2] Smith, B., Customer Satisfaction Is the Wrong Measure. The Gallup Management Journal 2005. Available at: http://www.gallup.com/businessjournal/15850/customer-satisfaction-wrong-measure.aspx. (Accessed July 15, 2021).

[3] Kendra L. (2021), The Top Ten Benefits of Customer Retention. Available at: https://blog.accessdevelopment.com/the-top-ten-benefits-of-customer-retention (Accessed July 16, 2021).

[4] SCHIFFMAN, L. G., et al., (2007). Consumer Behaviour. 9th ed. New Jersey: Prentice Hall. p-3

[5] Levy, M. and Weitz, B. A. (2007). Retailing Management. New York: McGraw Hill. P-599

[6] Mitchell G. (2020). Customer Services. Available at: https://www.investopedia.com/terms/c/customer-service.asp (Accessed July 15, 2021).

[7] Wreden, N. (2004), How to Recover Lost Customers, Available at: http://www.smartbiz.com/article/articleview/112/1/71. (Accessed July 16, 2021).

[8] Musasa, T. (2014). Customer Service and Its Impact on Consumer Purchasing Behaviour at Supermarkets in the Greater Area of Ethekwini. Unpublished Thesis, Durban University of Technology, Durban: South Africa.

[9] Vivek SD, Beatty SE, Morgan RM, Customer engagement: exploring customer relationships beyond purchase. Journal of Marketing Theory and Practice, 2012;20(2):122-146.

[10] Swick HM (2000). Toward a Normative Definition of Medical Professionalism. Acad. Med. 75(6):612-616

[11] Tylee, A., Haller, D. M., Graham, T., Churchill, R., \& Sanci, L. A. (2007). Youth-friendly primary-care services: how are we doing and what more needs to be done? The Lancet, 369(9572), 1565-1573.

[12] Swing SR (2007). The ACGME outcome project. Retrosp. Prospect. Med.1 Teacher 29:648-654.

[13] Bataineh, A. Q., Al-Abdallah, G. M., Salhab, H. A., \& Shoter, A. M. (2015). The effect of relationship marketing on customer retention in the Jordanian's pharmaceutical sector. International Journal of Business and Management, 10(3), 117-131.

[14] Kotler, P., \& Keller, K. (2016). Marketing Management. Pearson Education, England: United Kingdom.

[15] Aaahih P. (2021). Marketing Essentials - Sales Promotion, Definition, Strategies, \& Examples, Available at: https://www.feedough.com/sales-promotiondefinition-examples-types/(Accessed July 16, 2021).

[16] Chris J. (2019). Consumer Sales Promotion Techniques. Available at: https://smallbusiness.chron.com/consumer-sales-promotion-techniques-1035.html (Accessed July 16,2021$)$.

[17] N. Meena. (2021), Objectives of Sales Promotion, Available at: https://www.economicsdiscussion.net/sales/objectives-of-sales-promotion/31738 (Accessed July 17, 2021).

[18] CodeBlue (2020). Perikatan Continues Pakatan's Drug Price Control Proposal, Available at: https://codeblue.galencentre.org/2020/07/17/perikatan-continuespakatans-drug-price-control-proposal/ (Accessed July 17, 2021).

[19] Brooks, N., \& Simkin, L. (2012). Judging marketing mix effectiveness. Marketing Intelligence \& Planning, 30(5), 494-514.

[20] Rodney M. (2015). What Is the Physical Environment of a Business? - Definition, Components \& Examples, Available at: https://study.com/academy/lesson/whatis-the-physical-environment-of-a-business-definition-components-examples.html (Accessed July 17, 2021). 
[21] Sezgin, M., \& Küçükköylü, S. (2014). Store's Atmosphere's Importance in Creating Store's Image in Sustainable Management of Store and a Research in Konya (Turkey) City. Journal of Advanced Management Science, 2(3). 186-1

[22] Kaufman, C.F. 1996. A new look at one-stop shopping: a TIMES model approach to matching store hours and a shopper schedule. Journal of Consumer Marketing 13(1): 4- 52.

[23] Pride, W., Elliot, G., Rundle-Thiele, S., Waller, D. and Paladino, A. 2005. Marketing: Core Concepts and Applications, John Wiley \& Sons Australia. Reardon, T. and Timmer, P. 2005. SEARCA International Conference Agricultural and Rural Development in Asia: Ideas, Paradigms, and Policies Three Decades After, November 10-11, 2005: The supermarket revolution with Asian characteristics. Makati City, Philippines.

[24] Alpro Pharmacy Online Shop | Malaysia Best Pharmacy n.d. https://www.alpropharmacy.com/oneclick/ (Accessed August 17, 2021).

[25] Finn, A. (2001), "Mystery Shopper Benchmarking of Durables Goods Chains and Stores", Journal of Service Research, Vol. 3 No. 4, pp310-320

[26] HEINZ, V. AKADEMIE Dr. Orlity, s.r.o.: Mystery shopping - Tajny nakup [online]. Praha: c2002-2005 [7.9.2003] [cit. 1.9.2005]. DostupnyzWWW: http://www.orlita.cz/nowwwiny.php?start=1 (Accessed July 20, 2021).

[27] National Health and Morbidity Survey 2019, Available at: https://iptk.moh.gov.my/images/technical_report/2020/4_Infographic_Booklet_NHMS_2019_English.pdf pp28. (Accessed July 20, 2021).

[28] Victor R. PreedyRonald R. Watso, (2010) Handbook of Disease Burdens and Quality of Life Measures, ${ }^{\text {st }}$ Edition, pp 4288

[29] Gay, L. R., Mills, G. E., \& Airasian, P. (2009). Educational research: Competencies for analysis and applications. Columbus, OH: Merrill., pp. 150- 151

[30] Maurer, T. J., \& Pierce, H. R. (1998). A comparison of Likert scale and traditional measures of selfefficacy. Journal of Applied Psychology, 83(2), 324-329.

[31] Kursunluoglu E. Customer Service Effects on Customer Satisfaction and Customer Loyalty: A Field Research in Shopping Centers in Izmir City-Turkey. International Journal of Business and Social Science n.d.;2.

[32] Chua SS, Lim KP, Lee HG. Utilisation of community pharmacists by the general public in Malaysia. International Journal of Pharmacy Practice 2013; 21 :66-9. https://doi.org/10.1111/J.2042-7174.2012.00219.X. (Accessed July 20, 2021).

[33] Okai GA, Abekah-Nkrumah G, Asuming PO. Perceptions and trends in the use of community pharmacies in Ghana. Journal of Pharmaceutical Policy and Practice 2019 12:1 2019; 12:1-9. https://doi.org/10.1186/S40545-019-0186-X. (Accessed July 20, 2021).

[34] Key Elements of Customer Service - business.com n.d. https://www.business.com/articles/megan-totka-components-of-excellent-customer-service/ (Accessed August 16, 2021).

[35] Dubbai H, Adelstein B-A, Taylor S, Shulruf B. Definition of professionalism and tools for assessing professionalism in pharmacy practice: a systematic review. Journal of Educational Evaluation for Health Professions 2019;16. https://doi.org/10.3352/JEEHP.2019.16.22. (Accessed August 10, 2021).

[36] Iragorri N, Spackman E. Assessing the value of screening tools: reviewing the challenges and opportunities of cost-effectiveness analysis. Public Health Reviews 2018 39:1 2018; 39:1-27. https://doi.org/10.1186/S40985-018-0093-8. (Accessed August 10, 2021).

[37] About Us Corporate Profile - Alpro Pharmacy - Malaysia's Best Pharmacy n.d. https://www.alpropharmacy.com/about-us/ (Accessed August 17, 2021).

[38] Zain OM, Saidu MB. The Customers Satisfaction on Retailers' Brand Products: A Study on Selected Areas in Klang Valley. Procedia Economics and Finance 2016; 35:418-27. https://doi.org/10.1016/S2212-5671(16)00052-6. (Accessed August 17, 2021).

[39] Wan X, Evers PT, Dresner ME. Too much of a good thing: The impact of product variety on operations and sales performance. Journal of Operations Management 2012; 30:316-24. https://doi.org/10.1016/J.JOM.2011.12.002. (Accessed August 17, 2021).

[40] Saxena RP, al Hashemi B. Importance of location in successful retailing. International Journal of Knowledge, Culture and Change Management 2012;11:37-60. https://doi.org/10.18848/1447-9524/CGP/V11I01/49337. (Accessed August 18, 2021).

[41] Helmefalk M, Hultén B. Multi-sensory congruent cues in designing retail store atmosphere: Effects on shoppers' emotions and purchase behavior. Journal of Retailing and Consumer Services 2017; 38:1-11. https://doi.org/10.1016/J.JRETCONSER.2017.04.007. (Accessed August 18, 2021).

[42] Marshall Hargrave (2021), Kaizen, Available at: https://www.investopedia.com/terms/k/kaizen.asp\#: :text=Kaizen\%20is\%20a\%20Japanese\%20term,operations\%20and\%20involve\%20all\%20employees. (Accessed August 18, 2021).

\section{AUTHORS}

First Author - Steffi Ong Wei Mei, Bachelor of Pharmacy, Faculty of Pharmacy International Medical University, Malaysia Second Author - Yim Jing Yee, Bachelor of Pharmacy, Faculty of Pharmacy International Medical University, Malaysia 